\title{
Key Chagas disease missing knowledge among at-risk population in Spain affecting diagnosis and treatment
}

María Romay-Barja ${ }^{1,2^{*}}$, Laura Iglesias-Rus ${ }^{1}$, Teresa Boquete ${ }^{1,2}$, Agustín Benito ${ }^{1,2}$ and Teresa Blasco-Hernández ${ }^{1,2}$

\begin{abstract}
Background: Chagas disease is endemic in Latin America and, over the last few decades, due to population movements, the disease has spread to other continents. Early diagnosis and treatment are critical in terms of improving outcomes for those living with Chagas disease. However, poor knowledge and awareness is one of barriers that affects access to Chagas disease diagnosis and treatment for the population at risk. Information regarding immigrants' knowledge concerning Chagas disease control and prevention is insufficient in non-endemic countries and, therefore, this study sought to assess Chagas disease knowledge and awareness within the Bolivian community residing in Madrid.

Methods: This cross-sectional study was carried out in March-August 2017. A total of 376 Bolivians answered a structured questionnaire. A knowledge index was created based on respondents' knowledge about transmission, symptoms, diagnosis, and place to seek treatment. Multivariate logistic regressions analyses were performed to assess the factors associated with respondents' knowledge of Chagas disease.
\end{abstract}

Results: A total 159 (42.4\%) of Bolivians interviewed about their knowledge of Chagas disease were men and 217 (57.6\%) were women. Vinchuca was mentioned as mode of transmission by $71 \%$ of the Bolivians surveyed, while only $9 \%$ mentioned vertical transmission. Almost half of the Bolivians did not know any symptom of Chagas disease and only $47 \%$ knew that a specific blood test is necessary for diagnosis. Most of Bolivians were aware of the severity of Chagas disease, but $45 \%$ of Bolivians said that there is no cure for Chagas and $96 \%$ did not know any treatment. Based on the index of knowledge generated, only 34\% of Bolivians had a good knowledge about Chagas disease transmission, symptoms, diagnosis and treatment. According to the multiple logistic regression analysis, knowledge regarding Chagas disease, diagnosis and treatment was significantly higher amongst older Bolivians who had secondary education at least, as well as amongst those who had already been tested for Chagas disease.

Conclusions: This study found that most of the Bolivian population living in Spain had poor knowledge about Chagas disease transmission, symptoms, diagnostic methods and treatment. A poor understanding of the disease transmission and management is one of the most important barriers when it comes to searching for early diagnosis and appropriate care.

Keywords: Chagas disease, Knowledge, Barrier, Diagnosis, Treatment, Non-endemic country

*Correspondence: mromay@isciii.es

${ }^{1}$ National Centre of Tropical Medicine, Instituto de Salud Carlos III, Madrid, Spain

Full list of author information is available at the end of the article

\section{Background}

Chagas disease $(C D)$ is a parasitic disease caused by the flagellated protozoan Trypanosoma cruzi. Considered a neglected tropical disease, Chagas disease is endemic in original author(s) and the source, provide a link to the Creative Commons licence, and indicate if changes were made. The images or other third party material in this article are included in the article's Creative Commons licence, unless indicated otherwise in a credit line to the material. If material is not included in the article's Creative Commons licence and your intended use is not permitted by statutory regulation or exceeds the permitted use, you will need to obtain permission directly from the copyright holder. To view a copy of this licence, visit http://creativecommons.org/licenses/by/4.0/. The Creative Commons Public Domain Dedication waiver (http://creativeco mmons.org/publicdomain/zero/1.0/) applies to the data made available in this article, unless otherwise stated in a credit line to the data. 
21 countries in Latin America, where more than 6 million people are infected [1]. Over the last few decades, the disease has spread to other continents due to population movements. T. cruzi is transmitted to humans by triatomine bugs, popularly known as Vinchucas. Vertical transmission, blood transfusions or solid organ transplants are other routes of transmission that have a major role in non-endemic countries [2].

Chagas disease has an asymptomatic acute phase in which parasitaemia levels are higher; it then enters in an indeterminate chronic phase, with an absence of clinical symptoms of visceral involvement [3]. Up to $30 \%$ of chronically infected people develop cardiac alterations, and up to $10 \%$ develop digestive, neurological or mixed alterations which may require specific treatment. In chronic patients, antiparasitic treatment can potentially prevent or curb disease progression [1]. Recent studies have shown that treating infected women before pregnancy eliminates vertical transmission of T. cruzi $[4,5]$, whilst treatment efficacy is also especially high in congenitally infected newborns, with a cure rate of $100 \%$ [5]. The World Health Organization recently recommended implementing active strategies in Europe and other nonendemic regions in order to detect, screen and diagnose all infected pregnant women, as well as their infected newborns and siblings, and to treat them as expeditiously as possible [6].

It is estimated that the prevalence of $\mathrm{CD}$ amongst the Latin American population living in Europe is around $4.2 \%$ [7], and Spain is the European country with the highest burden of CD, with an estimated 52000 cases [8].

Early diagnosis and treatment are critical in order to improve outcomes for those living with $\mathrm{CD}$. However, scarce knowledge and awareness is one of the barriers that affects access to $\mathrm{CD}$ diagnosis and treatment for the population at risk [9], even in non-endemic countries. Misconceptions acquired in the country of origin are important barriers that prevent immigrants from undergoing screening [10]. Even when knowledge regarding $C D$ has not always being sufficient to change care-seeking behaviour [11], awareness has emerged as an important factor for being screened [12]. Community knowledge relating to vector-borne diseases varies depending on many sociodemographic factors such as gender, department of origin, rurality and educational status that may determine participation in control activities such as screening and treatment $[9,13,14]$. Improved knowledge of CD could lead communities to adopt better health-seeking related behaviours [15]. Awareness and knowledge should be understood and addressed in terms of their relationship with socioeconomic inequalities and gaps in the public health response to $\mathrm{CD}$, and cultural differences $[9,16]$. Therefore, more studies are needed about the knowledge of $\mathrm{CD}$ among the population at risk in non-endemic countries. This study sought to assess CD knowledge and awareness within the Bolivian community living in Madrid, Spain, in order to generate useful data for the design of public and private educational campaigns regarding $\mathrm{CD}$ aimed at promoting Chagas screening and treatment.

\section{Methods}

\section{Study area and population}

This cross-sectional study was carried out in MarchAugust 2017. The survey aimed to provide information regarding the knowledge, attitudes and practices of Bolivians living in Madrid, Spain. Based on the municipal census, a total of 15,951 Bolivians (6758 men and 9193 women) live in Madrid, distributed mainly throughout the neighbourhoods of Usera, Carabanchel, Puente de Vallecas and La Latina [17].

\section{Sampling and data collection}

A sample size of the Bolivian population living in Madrid was calculated based on a $95 \%$ confidence level, $5 \%$ error rate, and CD knowledge rate of $50 \%[18,19]$. A total of 376 people were selected amongst the Bolivians found in the waiting room of the Bolivian Consulate in Madrid. A structured questionnaire was administered to participants according to the percentages of men and women in the studied population. Inclusion criteria were that the respondents had to be over 18 years of age and they have ever heard about $\mathrm{CD}$ (only seven interviewed stated that they have never heard of CD).

Participants were asked about their knowledge, beliefs, and attitudes related to $\mathrm{CD}$. They were interviewed about their socioeconomic characteristics and knowledge related to the transmission and symptoms of $\mathrm{CD}$; diagnostic methods and treatment; and their attitudes towards the stigma associated with $\mathrm{CD}$. The questionnaire used was previously tested on the Bolivian population and in the same circumstances as the survey. The methodological aspects have been described elsewhere [20].

\section{Data analysis}

A descriptive univariate analysis of participant characteristics was conducted using frequency tables for categorical variables. For normally or not-normally distributed continuous variables, we used mean and standard deviation or median and interquartile range, respectively. Differences in sociodemographic characteristics and disease knowledge and attitudes between men and women were assessed using the Chi-squared test for independence for categorical variables. For normally or not-normally distributed continuous variables, we used the Student's $t$ test 
or the non-parametric Mann-Whitney test, respectively. $P$ values $<0.05$ were considered to be statistically significant. Data analyses were performed using STATA software version 15 (StataCorp LP, Texas, USA).

In order to assess the determinants of respondents' knowledge of $\mathrm{CD}$, a knowledge index was calculated, taking into account the answers they gave to some of the survey questions [21]. In order to achieve a maximum score of 10, the respondents had to know some general facts about CD: that CD is transmitted by the Vinchuca (1 point); other correct forms of transmission (1 point); any possible form of transmission in Spain (1 point); cardiovascular disorders constitute a main symptom of CD (1 point); digestive disorders constitute a main symptom of $\mathrm{CD}$ (1 point); other symptoms of $\mathrm{CD}$ (1 point); diagnostic methods ( 1 point); treatments for $C D$ ( 1 point); that it is possible to be tested and treated for CD in Spain (1 point); possible places where to be diagnosed and treated in Spain (1 point). Poor knowledge of CD was defined as scores either below or within the median. Scores above the median were considered as good knowledge.

The collinearity between independent variables was checked and, when present, the variable that explained the data distribution least was removed. A multiple logistic regression model was obtained using a backward stepwise procedure. The odd ratio $(O R)$ and $95 \%$ confidence interval $(C I)$ were computed. $P$ values $<0.05$ were considered statistically significant.

\section{Results}

A total of 376 Bolivians were interviewed regarding their knowledge of $\mathrm{CD}$, of which 159 (42.4\%) were men and 217 (57.6\%) were women. The socioeconomic and demographic characteristics of the surveyed population are summarized in Table 1 . The participants had a mean age of 38 years [interquartile range (IQR): $33-45$, minimum 18 , maximum 77]. Most of them $(76.1 \%$ of the men and $72.8 \%$ of the women) reported that they had completed secondary school studies or higher.

Concerning their place of origin, most of the Bolivians came from the Cochabamba and Santa Cruz departments ( $40.7 \%$ and $39.9 \%$, respectively). Moreover, $73.4 \%$ of the participants were from an urban area, whilst $26.6 \%$ came from rural environments.

Regarding their settlement in Madrid, the population surveyed was distributed throughout the city's districts in proportion to the municipal census. Most of them lived in the districts of Usera (19.4\%), Carabanchel (18.6\%), Puente de Vallecas (10.9\%), La Latina (8.2\%) and Ciudad Lineal (7.7\%). With respect to their economic situation, $68.3 \%$ of the participants had a job, presenting significant differences in terms of occupation and household income between men and women. The men worked mainly in services, sales, crafts and related trade jobs (54.7\%), whereas the women were more often employed in elementary occupations such as domestic cleaning or as helpers (66.9\%). Amongst the men, 61.6\% reported earning more than EUR 1000 as their household monthly income, whilst $50.7 \%$ of the women reported earning less.

With respect to health assistance, $87.0 \%$ of the surveyed Bolivians had the Public Health Insurance card. Moreover, $72.3 \%$ of the participants pointed out that they had not received any information about CD in Spain, and only $44.2 \%$ had been tested for CD.

\section{Chagas disease transmission knowledge}

Regarding CD transmission (see Table 2), $75.5 \%$ of the participants knew how it is transmitted, with differences between men and women $(70.4 \%$ and $79.3 \%$ respectively, $P=0.049)$. The main route of transmission identified was the Vinchuca bite $(71.3 \%, P=0.017)$, followed by blood transfusion (15.2\%) and vertical transmission (8.8\%). When asked about the possibility of $\mathrm{CD}$ transmission in Spain, $45.7 \%$ of Bolivians pointed out that it is possible; the main routes of transmission they identified were blood transfusion (24.2\%), Vinchuca bite (16.0\%), vertical transmission (6.9\%) and organ transplant transmission (3.7\%). Organ transplant transmission was identified more frequently by men than by women $(P=0.005)$.

In relation to the possibility of $\mathrm{CD}$ transmission during breastfeeding, $39.6 \%$ of the surveyed participants answered that there was no risk, whereas $33.0 \%$ considered it was possible.

\section{Signs and symptoms}

Regarding CD attitudes, $81.9 \%$ of the participants considered $C D$ to be a severe disease, although almost half of them did not know any symptom of CD (Table 3). Among those who affirmed to know some symptoms of CD, heart problems (28.5\%) and digestive disorders (9.6\%) were the most mentioned. Moreover, fever (9.6\%) was more frequently mentioned as a symptom by men than by women $(P=0.040)$, while fatigue was more mentioned by women.

\section{Knowledge and attitudes related to Chagas diagnosis}

A blood test was the first diagnostic method of CD mentioned by $78.7 \%$ of the surveyed participants (Table 4 ). Amongst these, $46.8 \%$ answered that it has to be a specific requested blood analysis. Asked about whether a CD test could be carried out in Spain, most of the population $(80.5 \%)$ knew that this opportunity exists. Regarding the place where they might go to be diagnosed, hospital (48.8\%) was the first health institution mentioned, followed by health centres (31.7\%). Community campaigns and blood banks were mentioned less. 
Table 1 Socio-economic and demographic characteristics of participants by sex

\begin{tabular}{|c|c|c|c|c|c|}
\hline & \multicolumn{2}{|l|}{ Male } & \multicolumn{2}{|l|}{ Female } & \multirow[t]{2}{*}{$P$-value } \\
\hline & $n=159$ & $\%$ & $n=217$ & $\%$ & \\
\hline \multicolumn{6}{|l|}{ Age, years } \\
\hline $18-24$ & 15 & 9.4 & 14 & 6.5 & \\
\hline $25-34$ & 47 & 29.5 & 48 & 22.1 & \\
\hline $35-44$ & 56 & 35.2 & 87 & 40.1 & \\
\hline $45-54$ & 27 & 17.0 & 46 & 21.2 & \\
\hline $55-64$ & 11 & 6.9 & 12 & 5.5 & \\
\hline$>65$ & 3 & 1.9 & 10 & 4.6 & 0.241 \\
\hline \multicolumn{6}{|l|}{ Education } \\
\hline Primary school or less & 38 & 23.9 & 59 & 27.2 & \\
\hline Secondary school or more & 121 & 76.1 & 158 & 72.8 & 0.471 \\
\hline \multicolumn{6}{|l|}{ Bolivian department } \\
\hline Cochabamba ${ }^{a}$ & 57 & 35.8 & 96 & 44.2 & \\
\hline Santa Cruz ${ }^{\mathrm{a}}$ & 68 & 42.8 & 82 & 37.8 & \\
\hline LaPaz & 18 & 11.3 & 17 & 7.8 & \\
\hline Potosi & 5 & 3.1 & 4 & 1.8 & \\
\hline Chuquisaca $^{a}$ & 4 & 2.5 & 5 & 2.3 & \\
\hline Oruro & 3 & 1.9 & 4 & 1.8 & \\
\hline Beni & 1 & 0.6 & 6 & 2.8 & \\
\hline Tarija $^{a}$ & 3 & 1.9 & 2 & 0.9 & \\
\hline Pando & 0 & 0.0 & 1 & 0.5 & 0.469 \\
\hline \multicolumn{6}{|c|}{ Departments according to Chagas disease prevalence } \\
\hline Non-endemic department & 27 & 17.0 & 32 & 14.8 & \\
\hline Endemic department & 132 & 83.0 & 185 & 85.3 & 0.327 \\
\hline \multicolumn{6}{|l|}{ Area } \\
\hline Rural & 42 & 26.4 & 58 & 26.7 & \\
\hline Urban & 117 & 73.6 & 159 & 73.3 & 0.521 \\
\hline \multicolumn{6}{|l|}{ Madrid district } \\
\hline Less than $10 \%$ of Bolivian population & 57 & 35.8 & 75 & 34.6 & \\
\hline More than $10 \%$ of Bolivian population & 102 & 64.2 & 142 & 65.4 & 0.440 \\
\hline \multicolumn{6}{|l|}{ Are you currently working? } \\
\hline No & 53 & 33.3 & 66 & 30.4 & \\
\hline Yes & 106 & 66.7 & 151 & 69.6 & 0.548 \\
\hline \multicolumn{6}{|l|}{ Jobs } \\
\hline Professionals, managers and technicians & 5 & 4.7 & 7 & 4.6 & \\
\hline Services and sales & 29 & 27.4 & 43 & 28.5 & \\
\hline Manual jobs & 72 & 67.9 & 103 & 68.2 & 0.911 \\
\hline \multicolumn{6}{|l|}{ Household income } \\
\hline None & 5 & 3.1 & 7 & 3.2 & \\
\hline$<$ EUR 1000 & 51 & 32.1 & 103 & 47.5 & \\
\hline EUR 1001-2000 & 81 & 50.9 & 86 & 39.6 & \\
\hline > EUR 2000 & 17 & 10.7 & 13 & 6.0 & \\
\hline Don't know & 5 & 3.1 & 8 & 3.7 & 0.032 \\
\hline \multicolumn{6}{|l|}{ Public Health Insurance card } \\
\hline No & 24 & 15.1 & 25 & 11.5 & \\
\hline Yes & 135 & 84.9 & 192 & 88.5 & 0.309 \\
\hline \multicolumn{6}{|c|}{ Received information about Chagas disease in Spain } \\
\hline No & 121 & 76.1 & 151 & 69.6 & \\
\hline Yes & 38 & 23.9 & 66 & 30.4 & 0.163 \\
\hline \multicolumn{6}{|l|}{ Tested for Chagas disease } \\
\hline No & 96 & 60.4 & 114 & 52.5 & \\
\hline Yes & 63 & 39.6 & 103 & 47.5 & 0.130 \\
\hline
\end{tabular}


Table 1 (continued)

a Departments where Chagas disease is endemic in Bolivia

Table 2 Bolivians' knowledge of Chagas disease transmission by sex

\begin{tabular}{|c|c|c|c|c|c|}
\hline & Male & $\%$ & Female & $\%$ & $P$-value \\
\hline \multicolumn{6}{|c|}{ Do you know how Chagas disease is transmitted? } \\
\hline Yes & 112 & 70.4 & 172 & 79.3 & \\
\hline No & 47 & 29.6 & 45 & 20.7 & 0.049 \\
\hline \multicolumn{6}{|l|}{ If so, how? ${ }^{a}$} \\
\hline Vinchuca bite & 103 & 92.0 & 165 & 95.9 & 0.017 \\
\hline Blood transfusion & 27 & 24.1 & 30 & 17.4 & 0.399 \\
\hline Vertical transmission & 13 & 11.6 & 20 & 11.6 & 0.725 \\
\hline \multicolumn{6}{|c|}{ Do you know if Chagas disease can be transmitted in Spain? } \\
\hline Yes & 89 & 56.0 & 83 & 38.3 & \\
\hline No & 40 & 25.2 & 93 & 42.9 & \\
\hline Don't know & 30 & 18.9 & 41 & 18.9 & 0.001 \\
\hline \multicolumn{6}{|l|}{ If so, how? } \\
\hline Blood transfusion & 48 & 53.9 & 43 & 51.8 & 0.020 \\
\hline Vinchuca bite & 30 & 33.7 & 30 & 36.1 & 0.120 \\
\hline Vertical transmission & 14 & 15.7 & 12 & 14.5 & 0.216 \\
\hline Organ transplant & 11 & 12.4 & 3 & 3.6 & 0.005 \\
\hline Sexual relations & 9 & 10.1 & 5 & 6.0 & 0.089 \\
\hline \multicolumn{6}{|c|}{ From an infected mother through breast milk? } \\
\hline Yes & 49 & 30.8 & 75 & 34.6 & \\
\hline No & 69 & 43.4 & 80 & 36.9 & \\
\hline Don't know & 41 & 25.8 & 62 & 28.6 & 0.441 \\
\hline
\end{tabular}

Table 3 Bolivians' knowledge and attitudes regarding Chagas disease symptoms by sex

\begin{tabular}{|c|c|c|c|c|c|}
\hline & Male & $\%$ & Female & $\%$ & $P$-value \\
\hline \multicolumn{6}{|c|}{ Is Chagas disease a serious disease? } \\
\hline Yes & 126 & 79.3 & 182 & 83.9 & \\
\hline No & 33 & 20.8 & 35 & 16.1 & 0.250 \\
\hline \multicolumn{6}{|c|}{ Chagas disease's symptoms ${ }^{a}$} \\
\hline Don't know & 74 & 46.5 & 96 & 44.2 & 0.658 \\
\hline Heart problems & 39 & 24.5 & 68 & 31.3 & 0.148 \\
\hline Fever & 21 & 13.2 & 15 & 6.9 & 0.040 \\
\hline Digestive disorders & 11 & 6.9 & 25 & 11.5 & 0.134 \\
\hline Fatigue & 13 & 8.2 & 22 & 10.1 & 0.518 \\
\hline Dizziness & 14 & 8.8 & 10 & 4.6 & 0.100 \\
\hline Headache & 10 & 6.3 & 13 & 6.0 & 0.905 \\
\hline
\end{tabular}

a Multiple choice question, answer is "yes"

Regarding confidence in health care, half of the Bolivians interviewed (53.5\%) believed that Spanish doctors are familiar with $\mathrm{CD}$, with $55.6 \%$ of the respondents showing a high level of confidence in these professionals when it comes to diagnosing and treating this disease. Asked about the need to perform a CD test amongst children of positive parents, $97.3 \%$ of the Bolivians surveyed highlighted the importance of screening children if the mother has a positive diagnosis, whilst another $86.9 \%$ claimed that screening was also necessary if the father has a positive diagnosis.

Regarding the possibility of having CD, most of the Bolivians interviewed ( $65.4 \%$ of the men and $53.9 \%$ of the women) did not believe they were infected.

\section{Treatment knowledge and attitudes}

Regarding the possibility of cure CD (see Table 5), 45.2\% of the Bolivians declared that there is no cure for Chagas disease and $96.0 \%$ did not know what the treatment for CD might be. Among those who said to know about a treatment, benznidazole was the most frequently mentioned (93.3\%). Although $80.6 \%$ of the Bolivians knew that it is possible to be treated in Spain and mentioned hospitals as the place to go for treatment (36.6\%), almost $39.2 \%$ did not know where to go for treatment. 
Table 4 Bolivians' knowledge and attitudes regarding Chagas disease diagnosis by sex

\begin{tabular}{|c|c|c|c|c|c|}
\hline & Male & $\%$ & Female & $\%$ & $P$-value \\
\hline \multicolumn{6}{|c|}{$\begin{array}{l}\text { Do you know what test is necessary to perform when a person has } \\
\text { Chagas disease? }\end{array}$} \\
\hline \multicolumn{6}{|l|}{ Blood test } \\
\hline Blood specific analysis & 69 & 56.1 & 107 & 61.8 & \\
\hline Blood routine analysis & 53 & 43.1 & 65 & 37.6 & 0.337 \\
\hline Don't know & 34 & 21.4 & 40 & 18.4 & 0.513 \\
\hline Xenodiagnosis & 2 & 1.3 & 5 & 2.3 & 0.370 \\
\hline \multicolumn{6}{|c|}{ Do you know if you can do a Chagas disease test in Spain? } \\
\hline Yes & 125 & 78.6 & 178 & 82.0 & \\
\hline No & 2 & 1.3 & 3 & 1.4 & \\
\hline Don't know & 32 & 20.1 & 36 & 16.6 & 0.678 \\
\hline \multicolumn{6}{|l|}{ If so, where? } \\
\hline Hospital & 55 & 44.0 & 93 & 52.3 & \\
\hline Health Centre & 47 & 37.6 & 49 & 27.5 & \\
\hline Don't know & 14 & 11.2 & 19 & 10.7 & \\
\hline Community campaigns & 6 & 4.8 & 10 & 5.6 & \\
\hline Blood bank & 3 & 2.4 & 7 & 3.9 & 0.397 \\
\hline \multicolumn{6}{|c|}{ Do you think doctors in Spain are familiar with Chagas disease? } \\
\hline Yes & 92 & 57.9 & 109 & 50.2 & \\
\hline No & 31 & 19.5 & 43 & 19.8 & \\
\hline Most are not & 27 & 17.0 & 48 & 22.1 & \\
\hline Don't know & 9 & 5.7 & 17 & 7.8 & 0.416 \\
\hline
\end{tabular}

How much confidence do you have in Spanish doctors to diagnose and treat Chagas disease?

$\begin{array}{lrrrrrl}\text { A lot of confidence } & 52 & 32.7 & 81 & 37.3 & \\ \text { Quite a lot of confidence } & 35 & 22.0 & 41 & 18.9 & \\ \text { Some confidence } & 30 & 18.9 & 37 & 17.1 & \\ \text { Little confidence } & 31 & 19.5 & 46 & 21.2 & \\ \text { No confidence at all } & 11 & 6.9 & 12 & 5.5 & 0.812 \\ \text { Do you think you might have Chagas disease? } & & & \\ \text { No } & 104 & 65.4 & 117 & 53.9 & \\ \text { Yes } & 46 & 28.9 & 76 & 35.0 & \\ \text { Don't know } & 9 & 5.7 & 24 & 11.1 & 0.046\end{array}$

If a mother knows she has Chagas disease, should her children be tested?

$\begin{array}{lrrrrr}\text { Yes } & 154 & 96.9 & 212 & 97.7 & \\ \text { No } & 2 & 1.3 & 4 & 1.8 & \\ \text { Don't know } & 3 & 1.9 & 1 & 0.5 & 0.376\end{array}$

And if a father knows he has Chagas disease, should his children be tested?

$\begin{array}{lrrrrr}\text { Yes } & 143 & 89.9 & 184 & 84.8 & \\ \text { No } & 12 & 7.6 & 22 & 10.1 & \\ \text { Don't know } & 4 & 2.5 & 11 & 5.1 & 0.292\end{array}$

a Multiple choice question, answer is "yes"

Asked about the administration of treatment, most of the surveyed population (96.8\%) said that they would take it. Furthermore, 99.2\% of the Bolivians stated that they would treat their children if positive. In the case of
Table 5 Bolivians' knowledge and attitudes regarding Chagas disease treatment by sex

$$
\text { Male } \% \quad \text { Female } \% \quad P \text {-value }
$$

Can Chagas disease be cured?

$\begin{array}{lrrrrr}\text { Yes } & 51 & 32.1 & 64 & 29.5 & \\ \text { No } & 69 & 43.4 & 101 & 46.5 & \\ \text { Don't know } & 35 & 22.0 & 38 & 17.5 & \\ \text { Depends on the progress } & 4 & 2.5 & 13 & 6.0 & \\ \text { Yes, in children under 1 year old } & 0 & 0.0 & 1 & 0.5 & 0.338\end{array}$

Do you know what the treatment for Chagas disease is?

$\begin{array}{lrrrrr}\text { Yes } & 5 & 3.1 & 10 & 4.6 & \\ \text { No } & 154 & 96.9 & 207 & 95.4 & 0.473\end{array}$

Do you know if Chagas disease can be treated in Spain?

$\begin{array}{lrrrrr}\text { Yes } & 125 & 78.6 & 178 & 82.0 & \\ \text { No, not in Spain } & 34 & 21.4 & 39 & 18.0 & 0.409 \\ \text { If so, where? } & & & & & \\ \text { Hospital } & 49 & 39.2 & 62 & 34.8 & \\ \text { Health centre } & 35 & 28.0 & 34 & 19.1 & \\ \text { Don't know } & 37 & 29.6 & 71 & 39.9 & \\ \text { Other } & 2 & 0.8 & 2 & 0.0 & 0.163\end{array}$

If you had Chagas disease, would you take the treatment?

$$
\begin{array}{lrrrrr}
\text { Yes } & 156 & 98.1 & 208 & 95.9 & \\
\text { No } & 3 & 1.9 & 9 & 4.2 & 0.218
\end{array}
$$

And if it were your child who had Chagas disease, would you treat him/ her?

$\begin{array}{rrrrrr}\text { Yes } & 158 & 99.4 & 215 & 99.1 & \\ \text { No } & 1 & 0.6 & 2 & 0.9 & 0.753\end{array}$

Can a pregnant woman receive Chagas disease treatment during pregnancy?

\begin{tabular}{lrrrrr} 
Yes & 16 & 10.1 & 18 & 8.3 & \\
No & 93 & 58.5 & 135 & 62.2 & \\
Don't know & 50 & 31.5 & 64 & 29.5 & 0.725 \\
\hline
\end{tabular}

pregnant women, $60.6 \%$ of the participants stated that it is not possible to be treated during pregnancy, whilst $30.3 \%$ did not know whether it is safe or not.

\section{Attitudes towards stigma}

With regard to stigma (see Table 6 ), $56.6 \%$ of the participants considered that the probability of having $C D$ was higher amongst people who lived in the countryside. Furthermore, poor people (14.1\%), residents in the warmer parts of Bolivia (10.9\%) and those living in adobe houses (10.1\%) were other factors mentioned.

In relation to the social rejection of people with $\mathrm{CD}$ in Spain, 59.6\% of the surveyed population stated that this was not a common experience. The reasons given to justify the absence of stigma in Spain were that the disease is not contagious (41.5\%), and lack of knowledge about CD amongst Spanish people (16.9\%).

Asked about who they would tell if they were diagnosed with $\mathrm{CD}$, the participants mentioned their 
Table 6 Bolivians' attitudes regarding Chagas disease stigma by sex

\begin{tabular}{|c|c|c|c|c|c|}
\hline & Male & $\%$ & Female & $\%$ & $P$-value \\
\hline \multicolumn{6}{|c|}{$\begin{array}{l}\text { What kind of people do you think are most likely to have Chagas } \\
\text { disease? }^{\text {a }}\end{array}$} \\
\hline People from the countryside & 85 & 53.5 & 128 & 59.0 & 0.285 \\
\hline Poor people & 21 & 13.2 & 32 & 14.7 & 0.672 \\
\hline All people equally & 15 & 9.4 & 31 & 14.3 & 0.156 \\
\hline $\begin{array}{l}\text { People from the warm parts of } \\
\text { Bolivia }\end{array}$ & 21 & 13.2 & 20 & 9.2 & 0.22 \\
\hline People living in adobe houses & 12 & 7.6 & 26 & 12.0 & 0.107 \\
\hline People living in small villages & 19 & 11.9 & 12 & 5.5 & 0.025 \\
\hline Elderly people & 9 & 5.7 & 2 & 0.9 & 0.007 \\
\hline \multicolumn{6}{|c|}{$\begin{array}{l}\text { Do you believe that people with Chagas disease are socially rejected in } \\
\text { Spain? }\end{array}$} \\
\hline Yes & 35 & 22.0 & 45 & 20.7 & \\
\hline No & 94 & 59.1 & 130 & 59.9 & \\
\hline Don't know & 30 & 18.9 & 42 & 19.4 & 0.955 \\
\hline \multicolumn{6}{|l|}{ If not, why? } \\
\hline $\mathrm{CD}$ is not contagious & 33 & 35.1 & 60 & 46.2 & \\
\hline $\begin{array}{l}\text { People in Spain don't know } \\
\text { about CD }\end{array}$ & 22 & 23.4 & 16 & 12.3 & \\
\hline It's a disease without symptoms & 7 & 7.4 & 19 & 14.6 & \\
\hline I haven't heard of any cases & 9 & 9.6 & 13 & 10.0 & 0.052 \\
\hline \multicolumn{6}{|c|}{ If you had Chagas disease, who would you tell? ${ }^{a}$} \\
\hline The whole family & 64 & 40.3 & 101 & 46.5 & 0.225 \\
\hline My partner & 88 & 55.3 & 59 & 27.2 & 0.000 \\
\hline Parents & 32 & 20.1 & 39 & 18.0 & 0.598 \\
\hline Children & 21 & 13.2 & 37 & 17.0 & 0.308 \\
\hline Medical practitioners & 9 & 5.7 & 20 & 9.2 & 0.202 \\
\hline Friends & 14 & 8.8 & 12 & 5.5 & 0.216 \\
\hline
\end{tabular}

a Multiple choice question, answer is "yes"

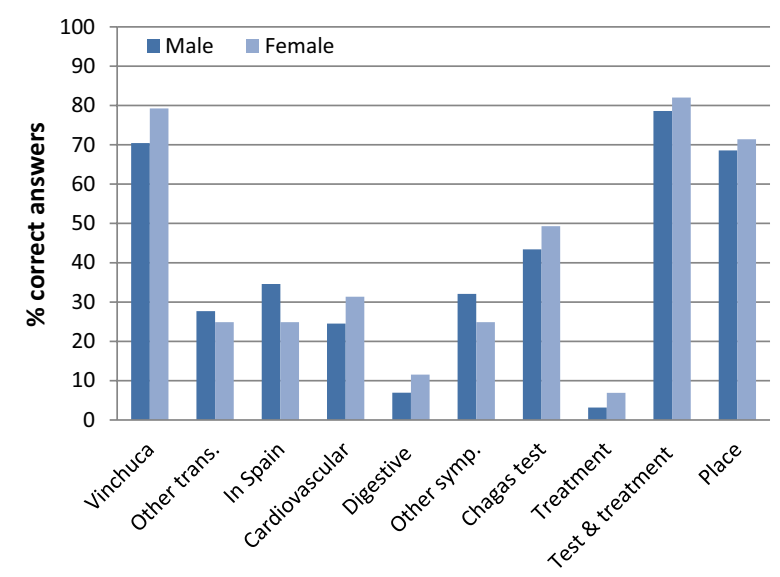

Fig. 1 Bolivians knowledge index about Chagas disease according to sex. Vinchuca: Chagas is transmitted by the Vinchuca; Other trans.: other correct forms of transmission; In Spain: Forms of transmission in Spain; Cardiovascular: cardiovascular disorders constitute a main symptom of Chagas; Digestive: digestive disorders constitute a main symptom of Chagas; Other symp.: other symptoms of Chagas; Chagas Test: actual diagnostic methods; Treatment: Nifurtimox or Benznidazole are the treatments for Chagas; Test and treatment: to know that in Spain it is possible to be tested and treated for Chagas; Place: places where it is possible to be diagnosed and treated in Spain

\section{Factors associated with Chagas disease knowledge}

According to the multiple logistic regression analysis (see Table 7), knowledge about CD, diagnosis and treatment was significantly better amongst older Bolivians who possessed at least secondary education, and amongst those who had been tested for $C D$. A better knowledge of $C D$ was also related to the respondents' perception of the severity of the disease. Other variables such as department of origin, years living in Spain, district and income were not associated with $C D$ knowledge index.

\section{Discussion}

This study found that most of the Bolivian population living in Spain had poor knowledge about CD transmission, symptoms, diagnostic methods and treatment, with CD knowledge being better among women. A poor understanding of $\mathrm{CD}$ is one of the most important barriers when it comes to searching for appropriate care, especially in a non-endemic country where there are no general health education campaigns regarding Chagas disease (Table 7).

Serious misconceptions regarding Chagas disease transmission emerged in this study. Bolivians mostly associated the transmission of CD with the Vinchuca, and some even mentioned the Vinchuca as a possible means of transmission in Spain. This representation of CD transmission is strongly linked with the country of origin was higher than that of men (Fig. 1). 
Table 7 Factors associated with Chagas disease Knowledge by multiple logistic regression

\begin{tabular}{|c|c|c|}
\hline & Unadjusted $O R(95 \% C l)^{\mathrm{a}}$ & $\begin{array}{l}\text { Adjusted OR (95\% } \\
C l)^{\mathrm{a}}\end{array}$ \\
\hline \multicolumn{3}{|l|}{ Age } \\
\hline$<40$ years & 1 & 1 \\
\hline 41 years or more & $1.88(1.22-2.90)$ & $1.9(1.18-3.05)$ \\
\hline \multicolumn{3}{|l|}{ Education } \\
\hline Primary school or less & 1 & 1 \\
\hline Secondary school or more & $1.58(0.96-2.60)$ & $2.2(1.27-3.89)$ \\
\hline \multicolumn{3}{|c|}{ Chagas disease is a severe disease } \\
\hline No & 1 & 1 \\
\hline Yes & $2.56(1.36-4.81)$ & $2.2(1.11-4.21)$ \\
\hline \multicolumn{3}{|l|}{ Received information } \\
\hline No & 1 & \\
\hline Yes & $2.08(1.31-3.30)$ & \\
\hline \multicolumn{3}{|l|}{ Tested for Chagas disease } \\
\hline No & 1 & 1 \\
\hline Yes & $3.52(2.27-5.47)$ & $3.69(2.32-5.87)$ \\
\hline
\end{tabular}

OR: odd ratio; $\mathrm{Cl}$ : confidence interval

${ }^{a}$ Only for the variables that remain in the model

$[12,22]$, where the populations at risk are largely aware of the relationship between this vector and the disease [14]. However, less than half of the Bolivians surveyed seemed to be aware about the possible transmission of $\mathrm{CD}$ in a non-endemic country such as Spain, and while vertical transmission was known, this was spontaneously mentioned by only $7 \%$ of participants. Misunderstandings about how transmission works were also found, with most of the Bolivians responding that it was necessary to test a child if either the father or mother were positive. Furthermore, some Bolivians answered that CD could be transmitted through breast-feeding. Uncertainties about the transmission of CD amongst migrant populations at risk living in Spain have been reported before [12, 23, 24]. Unfortunately, CD transmission knowledge does not seem to have improved over time. Increasing awareness regarding vertical transmission is crucial if the objective is to improve screening and treatment rates [6].

Most of the Bolivians living in Madrid were aware of the severity of Chagas disease. However, the symptoms of the disease were unknown to almost half of the respondents. Although awareness of the disease's severity is not common in other studies [9, 22], lack of knowledge regarding CD signs and symptoms is common [9, 12, 24, 25]. Chagas disease is a silent disease, one that is mostly asymptomatic during the indeterminate chronic phase, which makes it difficult to identify signs and later complications. The long period without symptoms that might affect everyday activities, added to the normalization of $\mathrm{CD}$, often keeps patients from being diagnosed and treated [26, 27].

Conversely, the Bolivians surveyed seemed to have a good knowledge of the Spanish health system and knew that it is possible to be tested and treated in Madrid. This could be linked to the number of years they have lived in Spain. The degree of confidence they have in Spanish doctors is also quite remarkable, even when almost $40 \%$ still doubt that doctors in Spain really know about CD. However, the majority of the Bolivians living in Madrid did not believe that they had CD, even when only $44 \%$ had been tested [28]. Diagnosis of CD produces a range of reactions in individuals, from scepticism to fear and anxiety [29]. It seems that the idea that "it is better not to know" found in other studies [12] reinforces the lack of interest in knowing more about the disease. Furthermore, most of the Bolivians knew that a blood analysis was necessary to know whether they were positive with $C D$, although almost $32 \%$ believed that this could be known with a routine analysis and, therefore, they did not ask their doctors for a specific diagnosis. Unfortunately, most non-endemic country health systems do not promote CD screening, because practitioners are not aware of $C D$, vertical transmission or the benefits of prompt diagnosis $[9,30]$. Improving awareness within the population at risk and amongst health workers has become a priority in order to boost diagnosis and treatment.

The idea that CD has no cure is still deeply rooted amongst the Bolivians interviewed and only one woman mentioned that $C D$ could be cured in children under 
one year of age. This widespread perception amongst the population at risk reinforces the idea that there is little point in diagnosing and treating the disease [23]. However, although there is confusion regarding treatment, they at least know that treatment is available [12, 27]. What is more, most of the Bolivians interviewed had a positive attitude towards being treated and towards treat their children. This attitude is present in various studies regarding the at-risk population living in non-endemic countries [22], although, unfortunately, this is not always consistent with their behaviour in terms of healthcare. Previous studies have shown that more than half of CDpositive Bolivians living in Madrid did not begin or complete treatment [28]. However, such positive attitudes towards treatment should be reinforced by improving their knowledge about the effectiveness of treatment at the disease's different stages.

Bolivians associated CD with poor people living in the rural areas of their country, but, at the same time, they did not believe that people with $\mathrm{CD}$ are rejected in Spain, mainly because it is not a contagious disease and almost nobody knows about the disease here. Although this might indicate that the perception of stigma has decreased in relation to the findings in other studies [27, 29, 31], almost none of the Bolivians mentioned their boss or colleagues when asked about whom they would tell if they had CD.

The factors associated with the Bolivians' knowledge index of CD consisted of age, education, awareness about the severity of the disease, and whether they had been tested for $\mathrm{CD}$. Young Bolivians had a poorest knowledge regarding $C D$ transmission, diagnosis and treatment. This association between poor knowledge of $\mathrm{CD}$ and Bolivians' age has been found in other regions of Spain [24], and this has become a serious problem if the aim is to treat women of childbearing age and young children [6].

Level of education and having been screened for CD are other factors associated with a better knowledge of the disease. It is clear that it is important to improve and extend educational campaigns in Spain by targeting the most vulnerable population at risk, through the existing specialised local associations and non-governmental organizations [32]. They must address the principal gaps in knowledge, especially those regarding transmission, diagnosis and treatment. Other studies have found that gaps in the at-risk population's knowledge of $C D$ are not only linked to their level of education, but may also be explained by doctor-patient communication [12]. Bolivians already screened for CD have a better knowledge because they have already received information about the disease from their doctors. Therefore, also improving the awareness of healthcare workers is essential so that they can provide adequate information to the population at risk [30]. A comprehensive approach is essential if we are to go beyond the biomedical aspects and address the multidimensional nature of the issue, while promoting an educational approach that allows individuals and communities to analyse and lead contextualised prevention and health promotion initiatives [33].

This study has certain limitations. First, it consisted of a cross-sectional study, so its findings may not be generally applicable to very different contexts. Second, people who answer that they had never heard of Chagas disease were not included in this study, meaning that information about some of the people at greatest risk might be excluded, despite the small number they represented. Third, due to the sample size, some associations may not show significance in the multivariable logistic regression.

\section{Conclusions}

In order to overcome existing barriers regarding diagnosis and treatment, it would be helpful to improve knowledge and understanding regarding $C D$ transmission and treatment. There is a need for participative educational programmes in non-endemic countries that would focus on certain key concepts:

- CD transmission occurs in non-endemic countries, mainly through vertical transmission;

- Prompt diagnosis and treatment of infected women before pregnancy could avoid vertical transmission;

- Existing treatments of Chagas cure the disease in children under the age of one and improve the prognosis in adults.

These educational campaigns should mainly target the young population at risk and primary health workers.

\footnotetext{
Abbreviations

CD: Chagas disease; Cl: Confidence interval; EUR: Euro; IQR: Interquartile range; OR: Odd ratio; USA: United States of America.

Acknowledgements

The authors thank the respondents for their voluntary participation and the Bolivian Consulate in Madrid for its essential assistance in the implementation of this study.

\section{Authors' contributions}

MRB and TBH designed and coordinated the study. MRB, TBH and TB carried out the survey. MRB conceived and designed the data analysis methods. TBH and MR participated in survey coordination and reviewed the manuscript. MR and $\mathrm{LI}$ performed the data analyses and wrote the manuscript. TBH, TB, and $A B$ reviewed and corrected the manuscript. All authors read and approved the final manuscript.
} 


\section{Funding}

This study was funded by the Instituto de Salud Carlos III (www.isciii. es) PI15CIII/00047 to TBH and the Tropical Diseases Research Network RD16CIII/003/001RICET (https://www.ricet.es). The funders had no role in study design, data collection and analysis, decision to publish, or preparation of the manuscript.

\section{Availability of data and materials}

Al data generated or analyzed during this study are included in this published article.

\section{Declarations}

\section{Ethics approval and consent to participate}

This study was approved by the Ethics Committee of the Spanish Carlos III National Health Institute (CEI PI 50_2016). Interviewees gave written informed consent to take part in the study.

\section{Consent for publication}

Not applicable.

\section{Competing interests}

The authors declare that they have no competing interests.

\section{Author details}

${ }^{1}$ National Centre of Tropical Medicine, Instituto de Salud Carlos III, Madrid, Spain. ${ }^{2}$ Collaborative Research Network on Tropical Diseases, RICET, Madrid, Spain.

Received: 16 November 2020 Accepted: 12 April 2021

Published online: 23 April 2021

\section{References}

1. Chagas disease. https://www.who.int/news-room/fact-sheets/detail/ chagas-disease-(american-trypanosomiasis). Accessed 3 Aug 2020.

2. Pérez-Molina JA, Molina I. Chagas disease. Lancet. 2018;391:82-94. https://doi.org/10.1016/S0140-6736(17)31612-4.

3. Rassi A, Rassi A, Marin-Neto JA. Chagas disease. Lancet. 2010:375:1388402. https://doi.org/10.1016/S0140-6736(10)60061-X

4. Álvarez MG, Vigliano C, Lococo B, Bertocchi G, Viotti R. Prevention of congenital Chagas disease by Benznidazole treatment in reproductive-age women. An observational study. Acta Trop. 2017;174:149-52. https://doi. org/10.1016/j.actatropica.2017.07.004

5. Murcia L, Simón M, Carrilero B, Roig M, Segovia M. Treatment of infected women of childbearing age prevents congenital Trypanosoma cruzi infection by eliminating the parasitemia detected by PCR. J Infect Dis. 2017;215:1452-8. https://doi.org/10.1093/infdis/jix087.

6. WHO. WHO | Preventing mother-to-child transmission of Chagas disease: from control to elimination. In: WHO. 2018. http://www.who.int/negle cted_diseases/news/Chagas-Preventing-mother-to-child-transmission/ en/. Accessed 7 May 2019.

7. Requena-Méndez A, Aldasoro E, de Lazzari E, Sicuri E, Brown M, Moore DAJ, et al. Prevalence of Chagas disease in latin-American migrants living in Europe: a systematic review and meta-analysis. PLoS Negl Trop Dis. 2015:9:e0003540. https://doi.org/10.1371/journal.pntd.0003540.

8. Basile L, Jansa JM, Carlier Y, Salamanca DD, Angheben A, Bartoloni A, et al. Chagas disease in European countries: the challenge of a surveillance system. Euro Surveill. 2011;16(37):19968.

9. Silva RAd, Wanderley DMV, Forsyth C, Leite RM, Luna EJdA, Carneiro Júnior $\mathrm{N}$, et al. Awareness of Chagas disease and socioeconomic characteristics of Bolivian immigrants living in Sao Paulo, Brazil. Rev Inst Med Trop Sao Paulo. 2020:62:e39. https://doi.org/10.1590/S1678-9946202062039.

10. Aguilar SJ. Vivir con Chagas en Madrid. Universidad Complutense de Madrid. 2016. https://eprints.ucm.es/37823/1/T37255.pdf.

11. Amieva C. El Chagas y las Ciencias Sociales: una mirada necesaria para una problemática compleja. Facultad de Ciencias Sociales, Universidad de Buenos Aires. 2013. https://www.aacademica.org/000-038/747.
12. Blasco-Hernández T, García-San Miguel L, Navaza B, Navarro M, Benito A. Knowledge and experiences of Chagas disease in Bolivian women living in Spain: a qualitative study. Glob Health Action. 2016;9:30201.

13. Rosecrans K, Cruz-Martin G, King A, Dumonteil E. Opportunities for improved Chagas disease vector control based on knowledge, attitudes and practices of communities in the yucatan peninsula, Mexico. PLoS Negl Trop Dis. 2014;8:e2763. https://doi.org/10.1371/journal.pntd.00027 63

14. Salm A, Gertsch J. Cultural perception of triatomine bugs and Chagas disease in Bolivia: a cross-sectional field study. Parasit Vectors. 2019;12:291. https://doi.org/10.1186/s13071-019-3546-0.

15. Sanmartino M, Crocco L. Knowledge about Chagas' disease and risk factors in Argentina communities with different epidemiological trends. Rev Panam Salud Publica. 2000;7:173-8. https://doi.org/10.1590/s1020-49892 000000300006

16. Donovan SD, Stevens M, Sanogo K, Masroor N, Bearman G. Knowledge and perceptions of Chagas disease in a rural Honduran community. Rural Remote Health. 2014;14:2845.

17. Padrón Municipal de Habitantes (explotación estadística) - Ayuntamiento de Madrid. https://www.madrid.es/portales/munimadrid/es/Inicio/ElAyuntamiento/Estadistica/Areas-de-informacion-estadistica/Demografiay-poblacion/Cifras-de-poblacion-y-censos-demograficos-/Padron-Munic ipal-de-Habitantes-\%28Explotacion-Estadistica\%29?vgnextfmt=detNa vegacion\&vgnextoid $=$ e5613f8b73639210VgnVCM1000000b205a0aRCRD \&vgnextchannel=a4eba53620e1a210VgnVCM1000000b205a0aRCRD\& $\mathrm{pk}=5720381$. Accessed 15 Oct 2018

18. Waseem H, Ali J, Sarwar F, Khan A, Rehman HSU, Choudri M, et al. Assessment of knowledge and attitude trends towards antimicrobial resistance (AMR) among the community members, pharmacists/pharmacy owners and physicians in district Sialkot, Pakistan. Antimicrob Resist Infect Control. 2019:24(8):67. https://doi.org/10.1186/s13756-019-0517-3.

19. Evlampidou I, Danis K, Lenglet A, Tseroni M, Theocharopoulos Y, Panagiotopoulos T. Malaria knowledge, attitudes and practices among migrants from malaria-endemic countries in Evrotas, Laconia, Greece, 2013. Eurosurveillance. 2015;20:21208. https://doi.org/10.2807/1560-7917.ES2015. 20.33.21208.

20. Romay-Barja M, Boquete T, Martinez O, Benito A, Blasco-Hernández T. Factors associated with Chagas screening among immigrants from an endemic country in Madrid, Spain. PLoS One. 2020;15:e0230120. https:// doi.org/10.1371/journal.pone.0230120.

21. Dhawan G, Joseph N, Pekow PS, Rogers CA, Poudel KC, Bulzacchelli MT. Malaria-related knowledge and prevention practices in four neighbourhoods in and around Mumbai, India: a cross-sectional study. Malar J. 2014;13:303. https://doi.org/10.1186/1475-2875-13-303.

22. Sanchez DR, Traina MI, Hernandez S, Smer AM, Khamag H, Meymandi SK. Chagas disease awareness among Latin American immigrants living in Los Angeles, California. Am J Trop Med Hyg. 2014;91:915-9. https://doi. org/10.4269/ajtmh.14-0305

23. Pérez-Ayala A, Pérez-Molina JA, Navarro M, López-Vélez R. Enfermedad de Chagas en personas procedentes de latinoamérica residentes en España. MINISTERIO DE SANIDAD Y POLITICA SOCIAL DE ESPAÑA. 2009. https:// www.mscbs.gob.es/en/profesionales/saludPublica/prevPromocion/ promocion/migracion/docs/enfermedadChagas.pdf.

24. Salvador-Gil V, Usero-Ruiz Al, Muñoz-Miguel J, Ortí-Lucas RM. Knowledge of Chagas disease in a bolivian population living in Valencia, Spain. J Epidemiol Res. 2017. https://doi.org/10.5430/JER.V3N2P7.

25. Navarro M, Berens-Riha N, Hohnerlein S, Seiringer P, von Saldern C, Garcia S, et al. Cross-sectional, descriptive study of Chagas disease among citizens of Bolivian origin living in Munich, Germany. BMJ Open. 2017:7:e013960. https://doi.org/10.1136/bmjopen-2016-013960.

26. Ventura-Garcia L, Roura M, Pell C, Posada E, Gascón J, Aldasoro E, et al. Socio-cultural aspects of Chagas disease: a systematic review of qualitative research. PLoS Negl Trop Dis. 2013;7:e2410. https://doi.org/10.1371/ journal.pntd.0002410.

27. Velasco M, Gimeno-Feliú LA, Molina I, Salas-Coronas J, Solà I, MongeMaillo B, et al. Screening for Trypanosoma cruzi infection in immigrants and refugees: Systematic review and recommendations from the Spanish Society of Infectious Diseases and Clinical Microbiology. Euro Surveill. 2020;25(8):1900393. https://doi.org/10.2807/1560-7917.ES.2020.25.8. 1900393 
28. Romay-Barja M, Boquete T, Martinez O, González M, Arco DÁ-D, Benito A, et al. Chagas screening and treatment among Bolivians living in Madrid, Spain: the need for an official protocol. PLoS One. 2019;14:e0213577. https://doi.org/10.1371/journal.pone.0213577.

29. Echeverría LE, Marcus R, Novick G, Sosa-Estani S, Ralston K, Zaidel EJ, et al. WHF IASC roadmap on Chagas disease. Glob Heart. 2020;15:26. https:// doi.org/10.5334/gh.484

30. Iglesias-Rus L, Romay-Barja M, Boquete T, Benito A, Blasco-Hernández T. The role of the first level of health care in the approach to Chagas disease in a non-endemic country. PLoS Negl Trop Dis. 2019;13:e0007937. https:// doi.org/10.1371/journal.pntd.0007937.

31. Ortí-Lucas RM, Parada-Barba MC, de la Rubia-Ortí JE, Carrillo-Ruiz A, Beso-Delgado M, Boone ALD. Impact of chagas disease in bolivian immigrants living in europe and the risk of stigmatization. J Parasitol Res. 2014;2014:514794. https://doi.org/10.1155/2014/514794.

32. Navarro M, Monge-Maílo B, Flores-Chavez MD, López-Vélez R. Hunting hidden parasites: Trypanosoma cruzi. Lancet Lond Engl. 2017;390:724-6. https://doi.org/10.1016/S0140-6736(17)31536-2.

33. Sanmartino M, Mateyca C, Pastorino IC. What are we talking about when we talk about education and Chagas? A systematic review of the issue. Biochim Biophys Acta Mol Basis Dis. 2020;1866:165691. https://doi.org/10. 1016/j.bbadis.2020.165691.
Ready to submit your research? Choose BMC and benefit from:

- fast, convenient online submission

- thorough peer review by experienced researchers in your field

- rapid publication on acceptance

- support for research data, including large and complex data types

- gold Open Access which fosters wider collaboration and increased citations

- maximum visibility for your research: over 100M website views per year

At BMC, research is always in progress.

Learn more biomedcentral.com/submissions 